\title{
PHOTOTHERMOGRAPHS, A TOOL FOR CLIMATE STUDIES IN RELATION TO THE ECOLOGY OF VEGETABLE VARIETIES
}

\author{
J. H. A. FERGUSON \\ Institute of Horticultural Plant Breeding - Wageningen, Netherlands \\ Received 15 Febr. 1957
}

\section{INTRODUCTION}

Weather and climate include numerous factors, such as temperature, precipitation, length of day, radiation, etc., many of which are intercorrelated. Generally climate types are described and defined as functions of both thermic and pluviometric properties, as for instance by KöPPEN, THORNTHWAITE and HUNTINGTON. These types have been successfully used in some sectors of agriculture.

It would not be adequate, however, to use one and the same climate criterion for objects which differ fundamentally with regard to limiting climatic factors. For instance agriculture is generally dependent on rainfall, but fishery is not. Vegetable crops are highly sensitive to the right amount of water. However, various species are grown successfully where rainfall is insufficient, if water is supplied by irrigation or sprinkling. Like soil tillering, manuring and spraying, control of water supply in such places may be looked upon as conditio sine qua non. It follows that precipitation need not necessarily be a primary climatic factor in relation to ecological studies on vegetables.

Surely there are places where vegetables are grown by natural water supply only. Whether this would be possible or not for a certain place, depends on factors such as rainfall, temperatures, radiation, wind, humidity, etc. Research in this direction may be attacked along lines promoted by PenMan and others. In the following pages, however, we will consider water as provided for.

Temperature of course is an important factor, which influences not only the growth of plants, but in many cases also controls the transition from one stage to another. The process of vernalization is one example. Since the publication of GARNER and ALLARD in 1920 it has become clear that some processes are directed by the length of day (or night). It was soon found, however, that for various plants certain critical day lengths are dependent on the temperature, so that the factors day length and temperature should be considered in combination. Eventually it has appeared that for various important vegetables from the genera Beta, Spinacia, Allium, and some varieties of Daucus carota there is an interrelation of temperature, day length and stage of development (WENT, WHYTE). 


\section{J. H. A. FERGUSON}

Therefore we will endeavour to find a form in which the photothermal climate may be expressed. The same form should be appropriate to express the limits of photothermal conditions which will effect certain physiologic processes in plants. In this paper this will be worked out to some extent for one certain phenomenon, viz. the transition from the vegetative stage to the generative stage (and vice versa) of Beta vulgaris.

\section{Photothermographs}

The relation between temperature and length of day has been represented by rectangular coordinates. To express the photothermal climate of a place, we have entered twelve dots, one for each month, and having for coordinates: the average day length and the average normal temperature. The months are indicated by numbers. The connection of the dots by straight lines or a closed curve yields a figure which we will call a climate-photothermograph. In figure 1 we have drawn the climatephotothermographs for Paramaribo (Suriname $6^{\circ} \mathrm{N}$ ), Cairo (Egypt, $30^{\circ} \mathrm{N}$ ), Perpignan (France, $42^{\circ} 42^{\prime} \mathrm{N}$ ), De Bilt (Netherlands, $52^{\circ} 07^{\prime} \mathrm{N}$ ), Oslo (Norway, $59^{\circ} 55^{\prime} \mathrm{N}$ ) and finally for Novgorod-Seversk (in the North of the Ukraina, $52^{\circ} 01^{\prime} \mathrm{N}$ ). Average

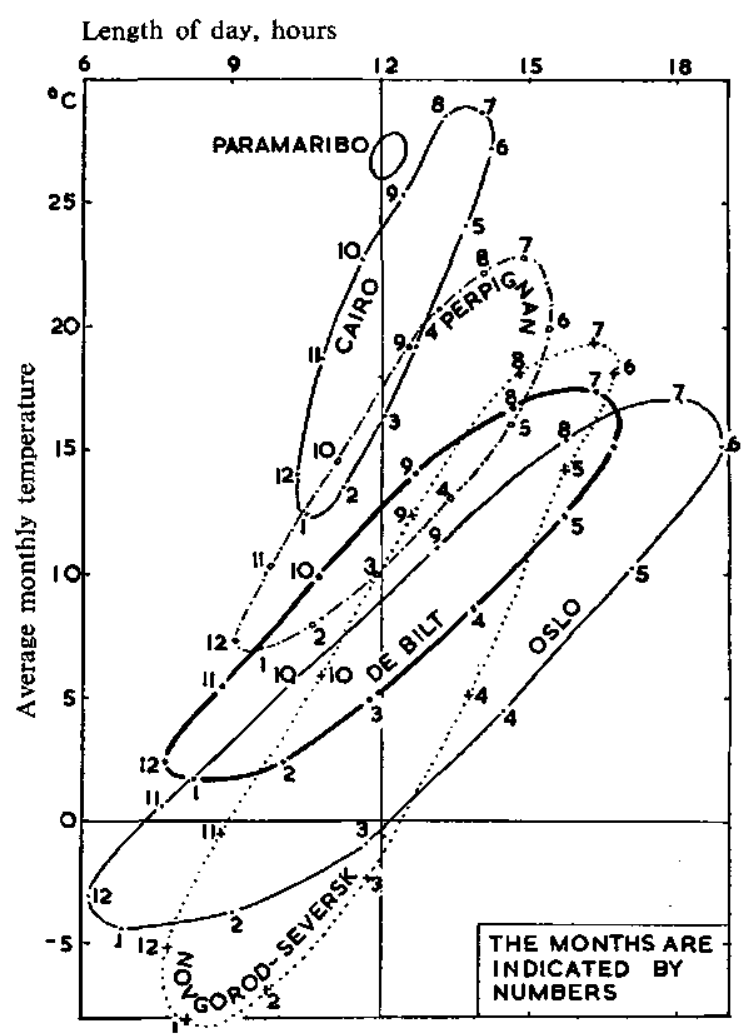

Fig. 1. Climate-PHOTOTHERMOGRAPHS OF SIX DifFERENT PLACES lengths of day have been derived from a table from the Royal Netherlands Meteorological Institute at De Bilt (see: BANGA, 3). Average monthly temperatures are read from KöPPEN's Handbuch, but for De Bilt, for which the averages from 1921/1950 have been used, as published by the Royal Netherlands Meteorological Institute, and for NovgorodSeversk, for which temperatures have been derived from NurTonSON.

The climate-photothermographs of course differ considerably. Novgorod-Seversk has the same latitude, and therefore the same day lengths as De Bilt, but it has a pronounced continental climate. The nearly constant character of the equatorial climate of Paramaribo is evident.

In figure 1 we have applied the average monthly values of the temperature. If there is reason to believe that either night or day temperatures, or their amplitudo, 
are explicitly responsible for a certain reaction, it might be useful to draw two additional curves, using average night temperature and daytime temperature as ordinates. Within one climate type the average monthly temperatures for day-time, night and natural day are highly correlated, so that it would not make much difference in result if, for instance, in a certain case average temperatures would be applied. If various climates are to be compared, however, the possible divergencies in daily amplitudo of the temperature should be kept in mind.

In the same way it is possible to construct a weather-photothermograph, based on the temperatures during a certain year or growing period, or for temperatures and photoperiods in a glasshouse. If conditions are kept constant for some time, the photothermograph appears as one single dot; in this case the length of the period during which these conditions were prevailing, should be indicated by a number.

Thus the photothermic conditions under which a plant has grown, or is expected to grow in a certain place, can be conveniently recorded.

\section{PHOtOTHERMOGRAPHS FOR CRITICAL CONDITIONS}

In this paper we shall apply climate-photothermographs to predict whether in a certain place Beta vulgaris can be grown to produce fleshy roots without premature bolting, i.e. before it becomes generative; or whether seed production will be promising. Therefore it is necessary to find out what combinations of photoperiod and temperature are critic values for beet crops to become generative. There is much literature available on this subject, from which we will only use those papers necessary to demonstrate the method.

ChroboczeK (5, see also BANGA, 2) has made extensive research using a strain of the Crosby variety of table beet. STEINBERG and GARNER (see BANGA, 2) experimented with sugar beets. Both have investigated under what combinations of photoperiod and temperature a vegetative beet plant will be induced to form a seed-stalk and vice versa. The transition from vegetative growth to generative growth of beet plants appears to be reversible in all developmental stages of the plant, depending on temperature and day length. Under the influence of relatively low temperatures and long photoperiods the equilibrium shifts in the direction of generative growth, and under relatively high temperatures combined with rather short days it shifts in the direction of vegetative growth. Table 1 summarizes their results and shows whether plants remained vegetative or appeared to have become generative under certain photothermic conditions.

The results in table 1 have been entered in the photothermographic chart in figure 2 , which has the same coordinate-axes as figure 1. Each combination of temperature and day length appears as a dot.

Now we want to draw a borderline between the region in the graph which contains the flower-inducing photothermal conditions and the region of the conditions under which the plants remain vegetative or are devernalized. It is quite clear that table beet and sugar beet may have different borderlines. It is known that, if stored in the dark, lifted beet roots are vernalized at temperatures below $10^{\circ} \mathrm{C}$, whereas higher temperatures will devernalize the roots. Therefore $10^{\circ} \mathrm{C}$ in zero hours of light may be considered a point in the borderline for both kinds. With continuous illumination all growing 
Table 1. Depending ON THE PHOtothermic CONDItions, a BeEt Plant Will develop either VEGETATIVELY (VEG.) OR GENERATIVELY (GEN.)

\begin{tabular}{|c|c|c|}
\hline \multicolumn{3}{|c|}{ Chrobozcek: Crosby table beet } \\
\hline \multirow{2}{*}{ Average temperature } & \multicolumn{2}{|c|}{ Average length of day } \\
\hline & $10 \frac{1}{2}$ hours & 15 hours \\
\hline 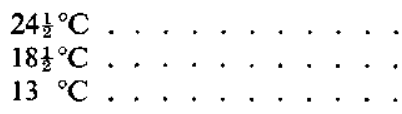 & $\begin{array}{l}\text { veg. } \\
\text { veg. } \\
\text { gen. }\end{array}$ & $\begin{array}{l}\text { veg. } \\
\text { neutral or slightly veg. } \\
\text { gen. }\end{array}$ \\
\hline
\end{tabular}

\begin{tabular}{|c|c|c|c|c|c|}
\hline \multicolumn{6}{|c|}{ SteInbERG and GARNER, Sugar beet } \\
\hline \multirow{2}{*}{\multicolumn{3}{|c|}{ Average temperature }} & \multicolumn{3}{|c|}{ Average length of day } \\
\hline & & & 15 hours & 18 hours & 24 hours \\
\hline $\begin{array}{l}24^{\circ} \mathrm{C} \\
18^{\circ} \mathrm{C} \\
16^{\circ} \mathrm{C}\end{array}$ & $\begin{array}{lllllll}. & . & . & . & . & . & . \\
. & . & . & . & . & . & . \\
. & . & . & . & . & . & . \\
\end{array}$ & . & $\begin{array}{l}\text { veg. } \\
\text { veg, } \\
\text { veg. }\end{array}$ & $\begin{array}{l}\text { veg. } \\
\left.\text { gen. }(66)^{1}\right) \\
\text { gen. }(65)\end{array}$ & $\begin{array}{l}\text { gen. (39) } \\
\text { gen. (46) } \\
\text { gen. (65) }\end{array}$ \\
\hline
\end{tabular}

$\left.{ }^{1}\right)$ Number of days from germination till the beginning of flowering.

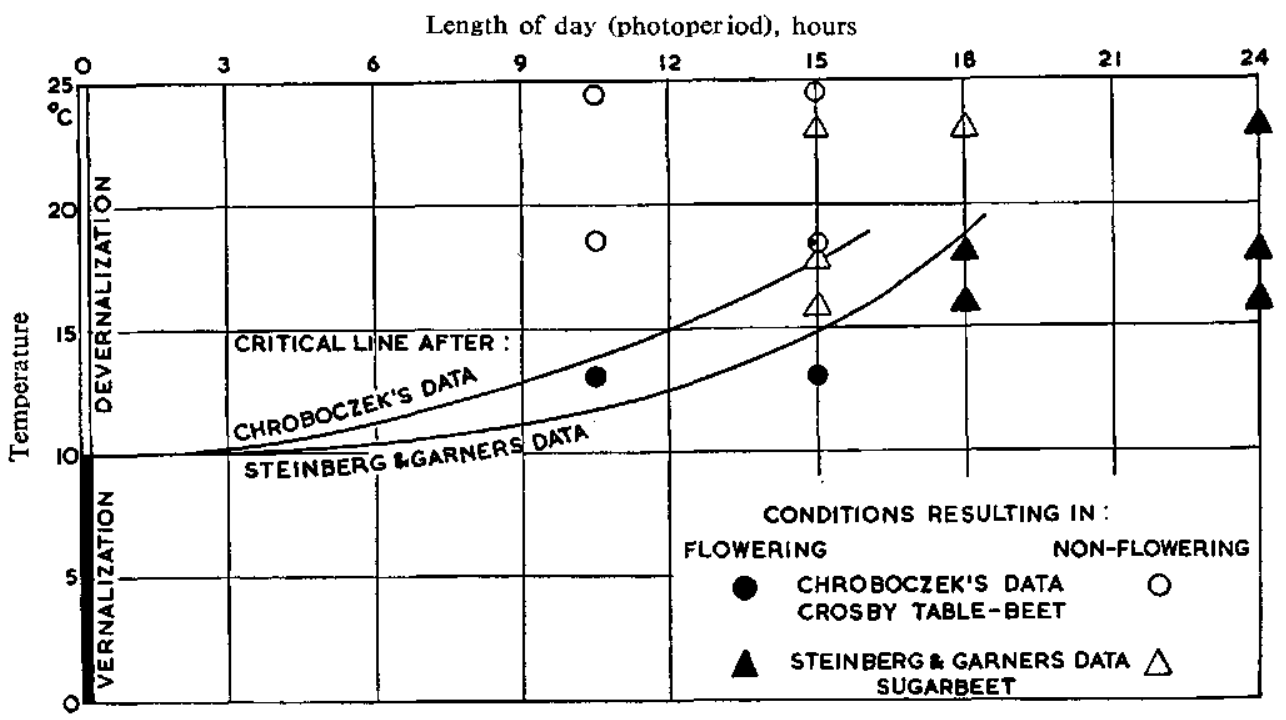

Fig. 2. Photothermograph to indicate eXPERIMENTAL RESUlts

temperatures studied so far appear to result in flowering. Under these conditions two lines have been drawn in figure 2 . When we speak of a "line", this should not be taken literally. If a group of plants is grown under just slightly flower-inducing conditions only a few individuals may develop seed stalks. Under normal conditions in the first year of development, when the fleshy root is growing, there are generally a few bolting plants, whereas in seed crops of Beta vulgaris a number of plants usually 


\section{PHOTOTHERMOGRAPHS FOR CLIMATE STUDIES}

remain vegetative. A stronger or longer vernalization would be required to induce the latter individuals to bear seed. So it is clear that each plant has an individual "borderline": for the non-bolters the line lies lower, for the premature bolters higher than the line as entered in the graph. Therefore it would be better to replace the expression "borderline" by "neutral zone", if such individual divergencies occur or are to be expected.

In figure 3 we have entered the neutral zone of Chroboczex's Crosby table beet in the climatephotothermograph of Ithaca, N.Y. (U.S.A.), where CHROBoczeK performed his investigations. From Boswell we know that the earliest sowing date for table beet is, as a rule, from 3 to 4 weeks before the average date of the last killing frost in spring. According to the Atlas of American Agriculture the last spring frost might be expected in Ithaca in the middle of May and so the earliest date of sowing would fall in the second half of April. From the graph we read that these plants would grow under vernalizing conditions during the first 5 or 6 weeks. This seems not to be enough for the bulk of the crop to start bolting. From various investigations it appears that for complete flowering Beta vulgaris needs a vernalization period of $1 \frac{1}{2}$ to 2 months or even longer, depending on the strength of the vernalization and the variety. Besides we know from CHroboczeK's data that young seedlings are slower in vernalizing than older plants. Therefore we might conclude that the Crosby which ChroboczeK used in his experiments in Ithaca might safely be grown there in the open.

It is clear that this same seed would not be quite

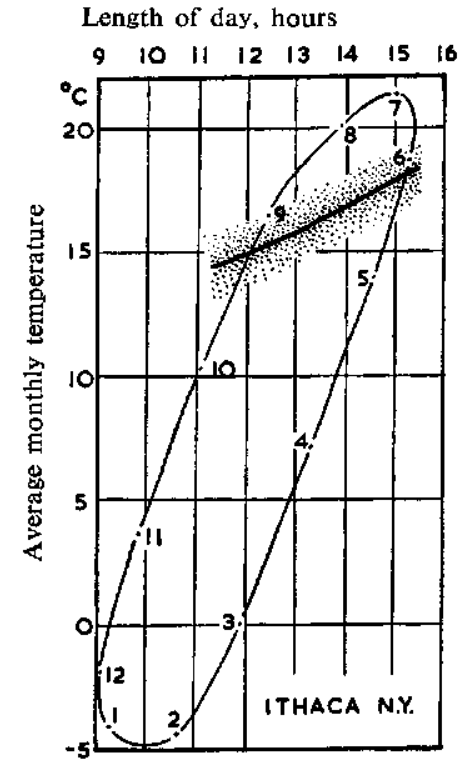

FIG. 3.

Climate-Photothermograph of ITHACA, N.Y., WITH THE NEUTRAL ZONE FOR VERNALIZATION FOR CROSBY TABLE BEET, ACCORDING TO CHROBOCZEK'S DATA suitable for beet production in Holland: the climate photothermograph of De Bilt (Netherlands) remains below the neutral zone during all months and consequently in most years the bulk of the crop would bolt in the first year. Dutch selections of this variety, however, are sown in Holland in the second half of May or in June; apparently their neutral zone has been lowered.

From investigations of Russel T. JoHnson and of N. A. NeGovskil it appears possible within a few generations to reduce appreciably the percentage of premature bolters in a variety. Lowering the percentage of bolters, i.e. relatively increasing the percentage of individuals with a low neutral line for vernalization, stimulates the vegetative growth and tends to increase production. There are, however, certain limits to the adaptation. TERRA mentions that Dutch varieties of table beet are successfully grown in Indonesia, in a tropical climate, but they never go to seed. This is quite clear: the photoperiod of about 12 hours is nearly constant, and the temperature is nearly constant as well, varying from 19 to $26^{\circ} \mathrm{C}$, depending on the altitude. These photothermic conditions are too far above the critical zone for Beta vulgaris. 


\section{Deduction of NeUtral zones From SOWING Dates}

Along empirical lines it is possible to estimate the position of neutral zones for varieties adapted to certain countries. We will work this out for varieties of Beta vulgaris under the conditions in Holland.

For seed-production beets are sown here at the end of May. In the first year the plants remain vegetative. Vernalization starts on the field when the temperature drops below about $10^{\circ} \mathrm{C}$, that is generally from the end of October, and is continued during winter, when the beets are stored in pits at relative low temperatures, preferably at about $5^{\circ} \mathrm{C}$. From experiments conducted by GAASTRA and ScHOOREL it appears that the temperature in the pit should preferably drop below $8^{\circ} \mathrm{C}$ from the beginning of the storing process, so as to give highest seed production. The beets are planted again around the first of April, after which the seed stalks appear in June and seed is harvested in August. Devernalizing conditions for more than 4 weeks during April and May would not fail to undo much of the vernalizing effect, especially for individuals that are difficult to vernalize. Therefore the neutral zone is expected to begin covering the climate-photothermograph not before the point indicating the beginning of May.

Sowing dates for beet production seem to give more exact information. Sugar beets are sown as early as possible, in order to obtain a good leaf production during the long days, which increases the sugar production. The varieties, which are highly resistant against premature bolting under the climate of Holland, are sown from the middle of March. Sowing in the beginning of March generally results in too high a percentage of premature bolters. As a vernalization period of two months must be considered prohibitive, even for these varieties, the neutral zone must be expected to cross the climate-photothermograph in the first half of May. Sugar beet varieties, which are less resistant against premature bolting and early table beets are sown in April. If early table beets are sown under glass in March, the glass is normally lifted in

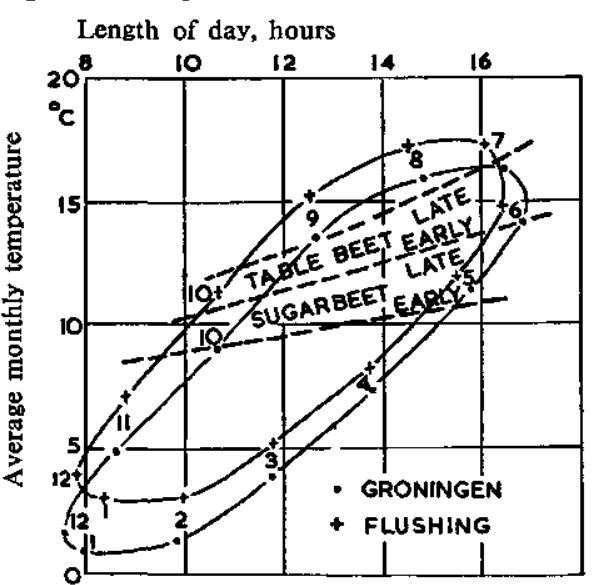

FIG. 4.

CliMATE-PHOTOTHERMOGRAPHS FOR GRONINGEN AND FLUSHING, WITH AN ESTIMATION OF THE NEUTRAL, LINES FOR VERNALIZATION, FOR LATE AND EARLY TABLE BEET AND SUGAR BEET
April. Summer varieties of table beets are sown at the end of May or early in June; the neutral zone must not cross the climatephotothermograph after the middle of June.

From these deductions we have estimated the borderlines for vernalization for Beta vulgaris varieties in the Netherlands as shown in figure 4 , together with the climatephotothermographs of two places, Groningen and Flushing, in the North and the South of the country.

The position of the neutral zone for the late summer varieties of table beets appears to be about $2^{\circ} \mathrm{C}$ lower as for Crosby in Ithaca in figure 3 . This must be considered as the result of local selection within the variety.

It seems justified to generalise that the 
indigenous varieties of biennial forms of beets must be in accordance with the climate of the country. The conditions will establish an equilibrium between early bolters and non-bolters. The latter group, i.e. plants for which vernalization has not been enough to induce flowering or which are devernalized again in late spring, do not go to seed. Early bolters will have no time to develop and therefore will remain small and bear only small amounts of seed.

\section{EXTREME CliMATES UNDER WHICH SUGAR BEET IS GROWN}

In figure 5 we have brought together the climate-photothermographs of some places which represent the most northern or southern regions of the northern hemisphere where sugar beet is planted, according to KLAGES. The surroundings of Bologna in Italy and Dodge City in Kansas
Length of day, hours

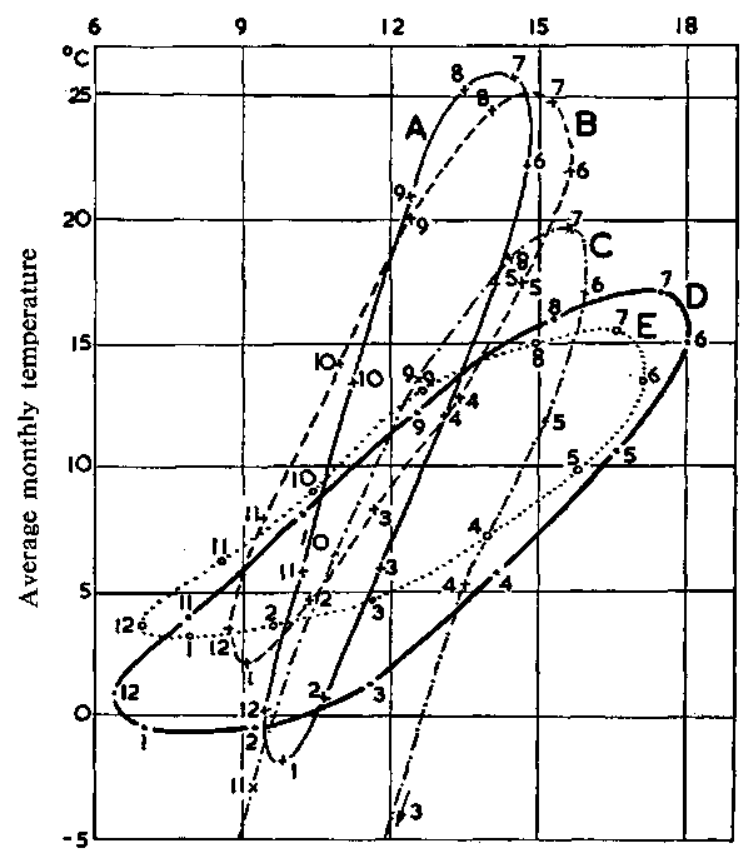

Fig. 5. Climate-photothermographs of:
A: Dodge City, Kansas, U.S.A. $38^{\circ} \mathrm{N}$.
B: Bologna, Italy, $45^{\circ} \mathrm{N}$.
C: Grand Forks, N. Dak. U.S.A., $43^{\circ}$ N.
D: Göteborg, Sweden, $58^{\circ} \mathrm{N}$.
E: Hull, England, $54^{\circ} \mathrm{N}$. are the warmest beet the regions in Europe and the United States. The sugar beet area north of Ankara, Turkey, has about the same photothermograph as these two. The coldest sugar regions of Europe are in England, of which Hull may be looked upon as a representative, and in Sweden, with Göteborg as a criterion. During the growing season both climates are colder than Groningen (Fig. 4). The North of the United States, Grand Forks in N. Dakota, is much warmer in summer, but April and October have the same or lower temperatures than Hull and Göteborg.

\section{Discussion}

In the foregoing pages we have applied a graph to indicate the climate of a place (or the weather conditions during a period) as far as the course of the factors length of day and temperature are involved. In addition we gave a conception of a matching graph to indicate a physiological property of a plant, in the present case the working of both factors on the transition from the vegetative to the generative stage of Beta vulgaris. We have not mentioned all research work published on this subject, as we are concerned with the method only. But as far as we can judge there are no results contrary to our interpretation. Many of the basic remarks are relevant to a large group of biennials (WENT). 


\section{J. H. A. FERGUSON}

If for other plant species the photothermic conditions under which the plant goes into flowering are more complicated, it might be necessary to find more than one critical reaction line, for instance one as a borderline for vernalizing conditions and another as a critical line for conditions effecting the vernalization so far reached.

It should be possible to find out under what photothermic conditions an optimal development will take place. If in addition a series of lines could be projected, each standing for a certain intensity of photothermic reaction, then the method would contribute greatly to estimating the productivity of a crop under certain climatic conditions.

\section{SUMMARY}

If water is supplied artificially, vegetables can be grown in various countries where rainfall is insufficient. Therefore precipitation need not necessarily be a primary climatic factor in relation to ecological studies in vegetable varieties. Most important climatic factors are day length and temperature, which control the growth and life cycle of many important species. A "photothermograph" has been designed to express a climate, or the weather conditions during a certain period, as far as the last two factors are concerned. Similarly the dependence of the growth and life cycle of a plant on the photothermic factors may be expressed. This has been worked out for a not too complicated problem: the transition from the vegetative to the generative stage, and vice versa, of some varieties of red table beet and sugar beet. For a few varieties the borderlines were found between the photothermic conditions which have a vernalizing effect, and those which result in devernalizing. A comparison of these borderlines with the climate photothermographs of some places gives rise to various considerations. It has been shown that this method, if worked out further, may probably contribute to predicting the productivity of a variety in a certain region.

\section{SAMENVATTING}

\section{Fotothermogrammen als hulpmiddel voor klimaatstudies in verband met de ecologie van groenterassen}

Kunstmatige watervoorziening maakt groenteteelt mogelijk in verschillende gebieden, waar de regenval onvoldoende is. Daarom behoeft aan neerslag niet noodzakelijkerwijs een primaire betekenis toegekend te worden, wanneer het gaat om een ecologische studie van groenterassen. Van grote betekenis daarentegen zijn de factoren daglengte en temperatuur, die tezamen de groei en de ontwikkelingscyclus van vele belangrijke groentegewassen bepalen.

Een grafische vorm is ontworpen: "fotothermogram" genoemd, waardoor een klimaat, dan wel de weersomstandigheden gedurende een zekere periode, weergegeven kunnen worden, voor zover het de daglengte en temperatuur betreft. Op eenzelfde grafiek kan men weergeven, hoe de ontwikkelingscyclus van een plant van deze twee factoren afhankelijk is. Dit laatste is uitgewerkt voor een betrekkelijk eenvoudig geval bij Beta vulgaris, t.w. de overgang van de vegetatieve naar de generatieve toestand, en omgekeerd. Voor enkele rassen van kroten en suikerbieten is de grenslijn gevonden tussen de vernaliserend en de devernaliserend werkende fotothermische omstandig- 


\section{PHOTOTHERMOGRAPHS FOR CLIMATE STUDIES}

heden. Vergelijking van deze grenslijnen met de klimaat-fotothermogrammen van een aantal plaatsen kan tot verschillende beschouwingen aanleiding geven. Nadere uitwerking van dit principe zal, naar verwacht wordt, een bijdrage kunnen leveren tot de prognose van de produktiviteit van een bepaald ras in een zeker gebied.

\section{LITERATURE CITED}

1. Atlas of American Agriculture, U.S. Govern. Printing Office, Washington D.C. 1936.

2. BANGA, O., Krotenstudies III: Vernalisatie en devernalisatie van bieten. Med. Dir. Tuinbouw, 11 (1948): 324-347.

3. BANGA, O., Injeiding tot de Plantenveredeling. Tjeenk Willink, Zwolle. 1953, 635 pp.

4. Boswell, V. R., Growing table Beets. U.S. Dep. Agric., Leaflet 360, 1954. 4 pp.

5. Chroboczer, E., A study of some ecological factors influencing seed-stalk development in beets. (Beta vulgaris L.) Memoirs 154, Cornell Univ., Agric. Exp. Sta., 1934, Ithaca, N.Y. 83 pp.

6. GaAstra, P., Bewaarproeven met pootbieten. Verslag C.I.L.O. over 1951. Wageningen, 1952. pp. 116-118.

7. JoHnson, R. T., The effect of successive seed increases. Proc. Amer. Soc. Sugar-Beet Technol. 8 (1954): 79-83.

8. Johnson, R. T., A rapid method of making a non-bolting selection in sugar beets. Proc. Amer. Soc. Sugar-Beet Technol. 8 (1954): 84-87.

9. KlaGes, K. H. W., Ecological Crop Geography. Mc. Millan, New York, 1942. pp. 458-459.

10. KöPPEN, W., Handbuch der Klimatologie, Tl. L and M. 1938.

11. MULDER, F., Handleiding voor de teelt van bietenzaden. Uitg.: Ceres, Meppel, 1954. 84 pp.

12. NegovskiI, N. A., Phasic development and the production of highyielding nonbolting varieties of sugar beet. Abstr. in: Plant Breeding Abstracts 25 (1) (1955) no. 435.

13. Nuttonson, M. Y., Ecol. crop geography of the Ukraine. Amer. Inst. Crop Ecol., Washington D.C., 1947. 24 pp.

14. SCHOOREL, A. F., Het bewaren van pootbietjes. Verslag C.I.L.O. over 1950. Wageningen, 1951. pp. 109-113.

15. Terra, G. J. A., Tuinbouw. In: De Landbouw in de Indische Archipel, Deel II A. Van Hoeve, 's-Gravenhage, 1948. pp. 662-746.

16. Went, F. W., The effect of temperature on plant growth. Ann. Rev. Plant Physiol. 4 (1953): $347-362$.

17. Whyte, R. O., Crop production and environment. Faber and Faber Ltd., London, 1946. 
64. Keuls, M. and J.W. Sieben. Two statistical problems in ! plant selection. April 1955 ... . . . . . . f 0.35

65. Banga, $O$. The lnstitute of Horticultural Plant Breeding. April 1955 ............ . . 0,25

66. Banga, $\boldsymbol{O}$. Uienveredeling met gebruikmaking van inteelt en herstel door heterosis. Juni 1955 ... . . . . f 0,30

67. Banga, 0 . Carroc yield analysis. September 1955; f 0,30

68. Banga, O.J. W. de Bruyn and L. Smeets. Selection of carrots for carotene content. II Sub-normal content at low temperature. September 1955. . . . . . . . . f 0.25

69. Braak, J. P. Effect of temperature and light on June Yellows in strawberries. September 1955 . . . . f 0.25

70. Banga, O. De ontwikkeling van de rassensituatie bij groentegewassen. Oktober $1955 \ldots$...... 0,25

71. Bruyne, A.S. de. Tendenzen in de ontwikkeling van het Nederlandse fruitsortiment. Oktober 1955 . . f 0,40

72. Banga, O. Praktijkproeven met Knolselderij 1953-1954. November 1955 . . . . . . . . . . . . . . . . f 0,30

73. Floor, J., Proeven met stekken onder waterverneveling. April 1956 ............ . . f 1,

74. Andeweg, j. $M$. en j. H. Ruyten. Praktijkproeven met Tomaten 1954-1955. April 1956 . . . . . . f 0,40

75. Andeweg, J. M. en A. van Steenbergen. Praktijkproeven met Scoksnijbonen 1953-1954. Mei 1956 . . . f 0,35

76. Banga, O. en J. L. van Bennokom. Praktijkproeven mez Ronde Witpunt Radijs 1953-1954. Mei 1956... f 0,55

77. Smeets, L. and Hester G. Kronenberg. Runner formation on strawberry plants in autumn and winter Smeets, L. Runner formation on strawberry plants in autumn and winter. II. Influence of the light intensity on the photoperiodical behaviour. Juni 1956 . . f 0,30

78. Smeets, L. Influence of the temperature on runner production in five strawberry varieties. Juni 1956 . . f 0,25

79. Smeets, L. and L. M. Wassenaar. Problems of heat spot in Fragaria vesca $L$. when indexing strawberry selections for viruses. Juni 1956 . . f 0,50

80. Banga, $O$. and $J$. W. de Bruyn. Selection of carrots for carotere content. III Planting distances and ripening equilibrium of the roots. Juni 1956 ........ f 0,35

81. Banga, $\mathcal{O}$. International conference on the improvement and on the standardization of vegetable varieties at Wageningen. Netherlands, on August 26 and $27,1955$. August 1956 ............. . . 0,75

82. Floor, J. Proeven met vermeerdering van houtige gewassen. September 1956 . . f 0,80

83. Gerritsen, C. J. Improvement of the cherry varieties used in the Netherlands. Oktober 1956 ..... f 0.35

84. Gerritsen, C. J. Research offered new possibilities for nut growing in the Netherlands. Oktober 1956.. f 0,25

85. Andeweg, J.M. The breeding of scab-resistant frame cu cumbers in the Netherlands. Oktoker 1956 . . . f0,30

86. Zeilinga, A. E. An improved acetic orcein squash method for serial cytological preparations. Oktober 1956 f0,20

87. Braak, J.P. and L.Smeets, The Phytotron of the institute of Horticultural Plant Breeding at Wageningen, the Netherlands. Oktober 1956.

88. Banga, $O$. and $L$, Smeets. Some effects of the photoperiod on growth and pithiness of radish. Okcober 1956. . . . . . . . . . . . . . . f 0,30

89. Kho, Y. O. and J. P. Braak. Reduction in the yield and viability of carrot seed in relation to the occurence of the plant bug Lygus campestris $L$. Oktober 1956. . f0,35
. Terpstra, $W$. Some factors influencing the abscission of debladed leaf petioles. Oktober 1956 . . f 0,35

91. Keuls, M. en J. J. Post. Invloed van de temperatuur op de groei van asperges. Januari 1957 . . . . f 0,70

92. Smeets, L. Some effects of the photoperiod on the shoot growth of cherry seedlings. Febr. 1957 . . f 0,30

93. Elzenga, G. and J. W. de Bruyn. Interrelation of alkaloid content and stage of development of 1. and 2-year - old - Atropa belladonna L. Febr. 1957.... . f0,30

94. Elzenga, G., L. Smeets and J. W. de Bruyn. Influence of the eemperature on growth and alkaloid content of first-year Atropa belladonna L. Februari 1957 . f0,25

95. Ferguson, J.H. A. Some applications of binomial probability paper in genetic analyses. Februari 1957 . 0,35

96. Jensma, J. R. Teelt en veredeling van bloemkool. Maart 1957............... f 3,50

97. Boom, B, K. Benarning, geschiedenis en kenmerken van een aantal houtachtige planten. Nomenclature, history and characteristics of some woody plants. Maart 1957... . . . . . . . . . . . . . f 2,50

98. Gerritsen, C.J. De Feyoa, een nieuw cultuurgewas? April 1957 ............. f 0,40

99. Braak, J.P. Effects of some internal and external factors on the embryo and seedling development of the cherry seedling. April 1957 . . . . . . . . . . f0,55

100. Floor, J. Moisture as a factor in the rooting of cuttings.

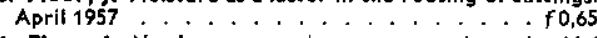

101. Floor, J. Verslag van onderstammen-onderzoek. Mei 1957.

102. Boom, B. K. Populus canadensis Moench versus Populus euramericana Guinier. April 1957 ..... . f 0,40

103. Huyskes, J. A. Moet Nederland groene en/of vezel vrije asperges gaan telen! Mei 1957..... f 0,40

104. Andeweg, J.M., en A. van Steenbergen. Praktijkproeven mec tuinbonen 1955-1956. Mei 1957 . . f 0.40

105. Banga, 0 . Origin of the European cultivated carrot; and Banga, 0 . The development of the original European carrot material. Juni $\$ 957$.......... . . f $1,-$

106. Andeweg, J. M., and J. H. Ruyten. Seven years experience with hybrid tomatoes. Juni 1957. . . f 0.50

07. Floor, J. Report on the selection of a dwarfing rootstock for cherries. Juni 1957.......... . f 0,40

108. Banga, $O$. Horticultural plant breeding in the Netherlands. Juni 1957

0,30

109. Giessen, A. C. van der, and A. van Steenbergen. A new method of testing beans for Anthracnose. Jun 1957 .

110. Huyskes, J. A. Praktijkproeven met witlol 1954-1955 Juli 1957

f 0,45

111. Ferguson, J. H. A. Photothermographs, a tool for climate studies in relation to the ecology of vegetable varieties. Okrober $1957 \ldots$......... f 0,55

112. Sneep, J. De geschiedenis van spinazie. Oktober 1957 . Der perse

113. Sneep, f.Teelten veredeling van spinazie (dissertatie Land. bouwhogeschool. Wageningen). Oktober 1957 ter perse

114. Smeets, L. Some effects of temperature on the shoot growth of cherry seedlings. Oktober 1957... 0,50

ENKELE ANDERE PUBLIKATIES VAN HET I.V.T.)

Jensma, J. R. Cabbage varieties / Sluitkoolrassen. 1956.

Leemans, J. A., and E. T. Nannenga. Raspberry varieties 1957 .

$f 13,50$

1) Zolang de voorraad strekt kunnen deze publikaties franco worden toegezonden, na ontvangst van het vermelde bedrag op giro no, 425340 van het Instituut voor de Veredeling van Tuinbouwgewassen, S. L. Mansholtlaan 15 te Wageningen onder vermelding van wat verlangd wordt; ook bestaat de mogelijkheid deze publikaties uit de bibliotheek van het I.V.T. te lenen. 